Journal of Bangladesh Academy of Sciences, Vol. 37, No. 1, 103-107, 2013

\title{
VARIETAL STUDY OF ANTHURIUM (ANTHURIUM ANDRAEANUM) AS A CUT FLOWER IN BANGLADESH
}

\author{
M.S. ISLAM, H. MEHRAJ, M.Z.K. RONI, S. SHAHRIN AND A.F.M. JAMAL UDDIN* \\ Department of Horticulture, Sher-e-Bangla Agricultural University, Dhaka, Bangladesh
}

\begin{abstract}
Five varieties viz., Caesar, Aymara, Ivory, Jewel, and Triticaca were in use for the study in Randomized Complete Block Design with five replications. Significant differences among cultivars were noted for all attributes evaluated. Variety 'Triticaca' had maximum stalk length and diameter, spathe length and breadth, spadix length, vase life and flowers per plant. Through present analysis it is noticed that, variety 'Titicaca' are exceedingly preferred because of its attractive flowers, excellent flower size, yield potentiality and long shelf life.
\end{abstract}

Key words: Anthurium, Cut flower, Vase life

\section{INTRODUCTION}

Anthurium (Anthurium andraeanum) is a slow-growing perennial flowering plant that requires shady, humid conditions as found in tropical forests. The genus anthurium is evergreen and belongs to the family Araceae as the plant possesses an underground rhizome with adventitious roots, characteristic of the family. Anthurium characteristically produces numerous inflorescences subtended by brightly colored spathes, which are carried on long, slender peduncles. Spathes are characteristically heart-shaped, flat, puckered and shiny and flowers have a wide range of spathe colors viz., white, pink, salmon-pink, red, light-red, dark-red, brown, green, lavender, cream or multi-colored. The colorful spathe is long-lasting. However, the 'true' flowers are found on the spadix and have large numbers of pistils, each surrounded by four stamens.

Anthurium ranks ninth in the global flower trade and commands a respectable price both for its cut flower and whole plant. Presently, the Netherlands is the world's leading producer and exporter followed by Mauritius. It is the national flower of Mauritius. In Bangladesh, the anthurium cut flower industry is still in its infancy. However, some progressive farmers and nursery men started growing anthurium and gaining popularity due to higher returns and their beautiful and attractive long lasting flowers. Considering the importance of this flower crop, there is a foremost need to evaluate some of the leading anthurium cultivars for cut flower production so that, suitable variety could be recommended for Bangladesh. Even though anthurium is grown by many growers in

*Corresponding author: <jamal4@yahoo.com>. 
Bangladesh; there is no scientific information about the use of high yielding varieties, standardization of suitable variety for yield, quality and vase life. Hence, identification of suitable varieties for yield, quality, and vase life is beneficial to the anthurium growers to obtain maximum yield of good quality flowers and returns. Keeping the above points in view, present investigation was taken up with following objectives that, to distinguish the yield performance of different varieties of anthurium commonly available in Bangladesh, under shade house condition and to assess the quality and vase life as cut flower.

Table 1. Morphological traits of anthurium cultivars based on spathe and spadix color.

\begin{tabular}{|c|c|c|c|}
\hline Anthurium cultivars & Spathe color & Spadix color & Photoes \\
\hline Caesar & Purple & Dark purple & \\
\hline Aymara & Pink & $\begin{array}{l}\text { Greenish } \\
\text { yellow } \\
\text { (Bicolor) }\end{array}$ & \\
\hline Ivory & Ivory & $\begin{array}{l}\text { Creamish } \\
\text { yellow }\end{array}$ & \\
\hline Jewel & Red & $\begin{array}{c}\text { Creamish } \\
\text { yellow }\end{array}$ & \\
\hline Triticaca & $\begin{array}{l}\text { White \& Green } \\
\text { (Bicolor) }\end{array}$ & $\begin{array}{l}\text { Greenish } \\
\text { yellow }\end{array}$ & \\
\hline
\end{tabular}

\section{MATERIALS AND METHODS}

The pot experiment was conducted at horticulture farm of Sher-e-Bangla Agricultural University, Dhaka-1207 during the period of May to October, 2011 for varietal analysis of anthurium cultivars as cut flower under shade house condition. Five anthurium cultivars viz. Caesar, Aymara, Ivory, Jewel, and Triticaca were used in RCBD with five replications (Table 1). Uniform and healthy suckers of anthurium were collected and planted in the month of May for the experimentation under shade house condition. The well decomposed coconut husk with cow dung, sand and small stones at proportion of $2: 1: 1: 1$ as growing media after washing in fungicide with pots of $35 \mathrm{~cm}$ 
$\times 35 \mathrm{~cm}$ in size were used in the experiment. The flowers were harvested after unfolding of the spathe was complete (Kamemoto 1962). Vase lives of all five varieties were conducted during the month of October. Five flowers were selected randomly from each cultivar and placed in a $200 \mathrm{ml}$ transparent flower vase containing $100 \mathrm{ml}$ tap water. Flower stalk ends were cut time to time and tap water was changed in every alternate days. The number of days until the spathe start wilted was recorded to evaluate the vase life. Collected data were statistically analyzed using MSTATC program. Mean was calculated and analysis of variance for each of the characters was performed by F-test. Difference between treatments was evaluated by DMRT at 5\% level of significance (Gomez and Gomez 1984).

\section{RESULTS AND DISCUSSION}

Data presented in (Table 2) showed the variation in different varieties with respect to flower stalk length. Variety Triticaca had tallest flower stalk $(40.5 \mathrm{~cm})$ while shortest stalk $(20.3 \mathrm{~cm})$ was recorded in Ivory. Jawaharlal et al. (1998) recorded that maximum stalk length is found in variety Amazonica compared to other six varieties. Henny (1999) recorded similar results in cultivar 'Red Hot'.

All varieties differed significantly with respect to the flower stalk diameter (Table 2). Variety Triticaca had maximum flower stalk diameter $(5.1 \mathrm{~mm})$ while minimum diameter $(3.0 \mathrm{~mm})$ was recorded in Caesar. This is a varietal trait as it is governed by the genetic makeup.

Spathe length significantly influenced by different varieties are presented in Table 2. Maximum spathe length was recorded in variety Triticaca $(15.3 \mathrm{~cm})$ whereas minimum $(6.3 \mathrm{~cm})$ was recorded in Ivory.

Different varieties showed significant effect on spathe breadth (Table 2). Maximum spathe breadth $(13.5 \mathrm{~cm})$ was recorded in variety Titicaca while minimum spathe breadth $(6.2 \mathrm{~cm})$ was recorded in Jewel. A temperature of $15^{\circ} \mathrm{C}$ to maximum of $30^{\circ} \mathrm{C}$ and relative humidity of $60-70 \%$ is ideal for the growth, which may influence the spathe breadth and varied among cultivars (Rajeevan et al. (2007).

Data presented in (Table 2) showed the variation in different varieties with respect to flower spadix length. Variety Titicaca had tallest spadix length $(8.1 \mathrm{~cm})$ while shortest was recorded in Ivory $(4.5 \mathrm{~cm})$.

Candle position significantly varied in different varieties as presented in Table 2. Variety Aymara showed minimum angle $\left(30.0^{\circ}\right)$ which is considered to be superior over other varieties and variety Jewel exhibited maximum angle $\left(60.0^{\circ}\right)$ which was inferior. All other varieties were found to be statistically different over the variety Jewel. 
Spathe angle significantly varied in different varieties Table 2. Variety Ivory had maximum spathe angle $\left(145.0^{\circ}\right)$ which was considered to be superior over other varieties and variety Jewel showed minimum angle $\left(100.0^{\circ}\right)$ which was considered as inferior. All other varieties were found to be statistically significant over the variety Jewel as found by Femina et al. (2006) and Nirmala (1996).

Different varieties significantly influenced the vase life Table 2. Results revealed that maximum vase life was observed in variety Titicaca (16 days) while minimum was recorded in Caesar (10 days). All other varieties were found to be statistically significant to each other. Vase life of flower is seemed to be an inherent capacity of the cultivar. These results are in line with that of Shriram et al. (2008) who showed similar results in variety 'Esmeralda'. Similar results were also recorded by Paull and Chantrachit (2001) and Thawiang et al. (2007 a,b).

Data presented in Table 2 put on view that there is an influence of varieties on production of number of flowers per plant. Maximum number of flowers per plant was recorded in variety Titicaca (7.2), while minimum (4.1) was recorded in Ivory. Binodh et al. (2005), Srinivasa and Reddy (2005), Rajeevan et al. (2007), Shiva and Nair (2008) and Shriram et al. (2008) recorded similar results with respect to flower production.

Table 2. Performance of anthurium cultivars ${ }^{\mathrm{x}}$.

\begin{tabular}{lccccccccc}
\hline Cultivars & $\begin{array}{c}\text { Flower } \\
\text { stalk } \\
\text { length } \\
(\mathrm{cm})\end{array}$ & $\begin{array}{c}\text { Flower } \\
\text { stalk } \\
\text { diameter } \\
(\mathrm{mm})\end{array}$ & $\begin{array}{c}\text { Spathe } \\
\text { length } \\
(\mathrm{cm})\end{array}$ & $\begin{array}{c}\text { Spathe } \\
\text { breadth } \\
(\mathrm{cm})\end{array}$ & $\begin{array}{c}\text { Spadix } \\
\text { length } \\
(\mathrm{cm})\end{array}$ & $\begin{array}{c}\text { Candle } \\
\text { position } \\
\left({ }^{0} \text { angle }\right)\end{array}$ & $\begin{array}{c}\text { Spathe } \\
\text { angle }\left({ }^{0}\right)\end{array}$ & $\begin{array}{c}\text { Vase } \\
\text { life }\end{array}$ & $\begin{array}{c}\text { Flowers/ } \\
\text { plant }\end{array}$ \\
\hline Caesar & $27.1 \mathrm{~b}$ & $3.0 \mathrm{~d}$ & $10.4 \mathrm{c}$ & $10.8 \mathrm{c}$ & $6.6 \mathrm{~b}$ & $43.0 \mathrm{c}$ & $120.0 \mathrm{c}$ & $10.0 \mathrm{~d}$ & $4.5 \mathrm{~d}$ \\
Aymara & $25.2 \mathrm{c}$ & $3.7 \mathrm{c}$ & $8.1 \mathrm{~d}$ & $11.3 \mathrm{~b}$ & $6.9 \mathrm{~b}$ & $30.0 \mathrm{e}$ & $135.0 \mathrm{~b}$ & $12.0 \mathrm{c}$ & $5.7 \mathrm{c}$ \\
Ivory & $20.3 \mathrm{e}$ & $3.2 \mathrm{~d}$ & $6.3 \mathrm{e}$ & $9.0 \mathrm{~d}$ & $4.5 \mathrm{~d}$ & $35.0 \mathrm{~d}$ & $145.0 \mathrm{a}$ & $14.0 \mathrm{~b}$ & $4.1 \mathrm{~d}$ \\
Jewel & $22.5 \mathrm{~d}$ & $4.2 \mathrm{~b}$ & $11.3 \mathrm{~b}$ & $6.2 \mathrm{e}$ & $5.5 \mathrm{c}$ & $60.0 \mathrm{a}$ & $100.0 \mathrm{~d}$ & $12.0 \mathrm{c}$ & $6.6 \mathrm{~b}$ \\
Triticaca & $40.5 \mathrm{a}$ & $5.1 \mathrm{a}$ & $15.3 \mathrm{a}$ & $13.5 \mathrm{a}$ & $8.1 \mathrm{a}$ & $50.0 \mathrm{~b}$ & $120.0 \mathrm{c}$ & $16.0 \mathrm{a}$ & $7.2 \mathrm{a}$ \\
\hline
\end{tabular}

${ }^{\mathrm{x}}$ In a column means having similar letter (s) are statistically identical and those having dissimilar letter (s) differ significantly as per 0.05 level of probability.

\section{CONCLUSION}

Anthurium is grown for the most part as a cut flower crop and valued for their colorful long lasting spathe and spadix. For its massive effect, elegance and variety of colors, anthurium attract vast majority of growers and consequently need to standardize the growing techniques. Through present analysis it is noticed that, variety 'Titicaca' is exceedingly preferred by the anthurium user, because of its attractive flowers, excellent flower size, yield potentiality and long shelf life. 


\section{REFERENCES}

Binodh, A. K. and P. M. Devi. 2005. Selection indices and per se performance of morphologically diverse Anthurium genotypes. Indian J. Genet. Plant Breed. 65(1): 65-66.

Femina, Valsalakumari and P. K. Rajeevan. 2006. Performance of anthurium (Anthurium andreanum Lind.) cultivars under different systems of growing in humid tropical plains. $J$. Ornamental Hort. 9(4): 274-277.

Gomez, A. K. and A. A. Gomez. 1984. Statistical Procedures for Agricultural Research, 2nd Ed., John Wiley and Sons, Inc., NY. pp. 8-20.

Henny, R. J., 1999. 'Red Hot' anthurium. Hort Science 34(1): 153-154.

Jawaharlal, M., K. Soorianatha Sundaram, G. Balakrishna-Murthy and S. Thamburaj, 1998. Performance of anthurium cultivars at Yercaud. . Paper presented In: National Seminar on Anthurium production, Organized by IIHR, Bangalore, 2-3 June, 1998, Chettahalli, Coorg.

Kamemoto, H. 1962. Some factors affecting the keeping quality of anthurium flowers. Hawaii Farm Sci. 11(4): 204.

Nirmala, K. 1996. Micropropagation and genotypic conformity in Anthurium andreanum L. Ph.D. Thesis Uni. Agric. Sci., Bangalore (India).

Paull, R. E. and T. Chantrachit. 2001. Benzyladenine and the vase life of tropical ornamentals. Postharvest Biol. Tech. 21(3): 303-310.

Rajeevan, P. K., P. K. V. Kumari, V. P. Rao, P. V. Liji and Sujitha-Mohan. 2007. Performance evaluation of cut flower varieties of anthurium under two agro-climatic conditions. $J$. Ornamental Hort. 10(3): 177-180.

Shiva, K. N. and S. A. Nair. 2008. Performance of anthurium cultivars in Andamans. Indian J. Hort. 65(2): 180-183.

Shriram, N., R. Ambad, M. T. Anita, Shetye and Patil, 2008. Varital performance of anthurium (Anthurium andreanum L.) under cost effective Polyhouse. 3rd Indian Hort. Congress, India, 2008.

Srinivasa, V. and T. V. Reddy. 2005. Evaluation of different varieties of anthurium under hill zone of Coorg District, Karnataka. Mysore J. Agric. Sci. 39(1): 70-73.

Thawiang, N., M. Buanong and S. Kanlayanarat. 2007a. Effect of thidiazuron on postharvest quality of cut flowers of anthurium (Anthurium andraeanum L. cv. Marshall). Acta Hort. 75(5): 415-418.

Thawiang, N., M. Buanong and S. Kanlayanarat. 2007b. Effect of thidiazuron on postharvest quality of cut flowers of anthurium (Anthurium andraeanum L. cv. Marshall). Acta Hort. 75(5): 419-423.

(Received revised manuscript on 9 April, 2013) 